\section{The diabetes gene Hhex maintains $\delta$-cell differentiation and islet function}

\author{
Jia Zhang, ${ }^{1}$ Lindsay B. McKenna, ${ }^{1}$ Clifford \\ W. Bogue, ${ }^{2}$ and Klaus H. Kaestner ${ }^{1,3}$ \\ ${ }^{1}$ Department of Genetics and Institute for Diabetes, Obesity, \\ and Metabolism, Perelman School of Medicine, University of \\ Pennsylvania, Philadelphia, Pennsylvania 19104, USA; \\ ${ }^{2}$ Department of Pediatrics, Yale University School of Medicine, \\ New Haven, Connecticut 06510, USA
}

The homeodomain transcription factor HHEX (hematopoietically expressed homeobox) has been repeatedly linked to type 2 diabetes mellitus (T2DM) using genomewide association studies. We report here that within the adult endocrine pancreas, Hhex is selectively expressed in the somatostatin-secreting $\delta$ cell. Using two mouse models with Hhex deficiency in the endocrine pancreas, we show that Hhex is required for $\delta$-cell differentiation. Decreased somatostatin levels in Hhex-deficient islets cause disrupted paracrine inhibition of insulin release from $\beta$ cells. These findings identify Hhex as the first transcriptional regulator specifically required for islet $\delta$ cells and suggest compromised paracrine control as a contributor to $\mathrm{T} 2 \mathrm{DM}$.

Supplemental material is available for this article.

Received November 26, 2013; revised version accepted March 17, 2014.

Although genome-wide association studies have linked $>60$ loci with type 2 diabetes mellitus (T2DM), how these loci contribute to the pathogenesis of diabetes remains largely undetermined. Multiple single-nucleotide polymorphisms (SNPs) in a 350-kb linkage disequilibrium (LD) block on human chromosome 10 have been strongly linked to T2DM (Saxena et al. 2007; Schulze et al. 2007; Scott et al. 2007), impaired insulin secretion (Jonsson et al. 2013), elevated glucagon secretion (Jonsson et al. 2013), and higher pediatric body mass index (Zhao et al. 2010). This LD block encompasses three genes: IDE (insulin-degrading enzyme), KIF11 (kinesin-interacting factor 11), and HHEX (hematopoietically expressed homeobox). A recent study from the Edlund laboratory (Steneberg et al. 2013) discovered that Ide is required for insulin secretion in mouse $\beta$ cells. However, it remains unknown whether and how KIF11 and/or HHEX are involved in glycemic control.

In mice, Hhex is a crucial regulator in the development of several organs, including the heart (Foley and Mercola 2005), thyroid (Fagman and Nilsson 2011), and liver (Bort

[Keywords: diabetes; transcription factors; somatostatin; pancreatic islet; $\delta$ cell]

${ }^{3}$ Corresponding author

E-mail kaestner@mail.med.upenn.edu

Article is online at http://www.genesdev.org/cgi/doi/10.1101/gad.235499.113. et al. 2006; Hunter et al. 2007). Hhex ${ }^{-/-}$embryos die at midgestation and evince a variety of defects, including failure to specify the ventral pancreas due to blunted migration of foregut endoderm cells (Bort et al. 2004). In adults, Hhex activity has been described in the mouse lung, thyroid, and liver (Bogue et al. 2000). However, Hhex protein expression and function have not been reported in the mature rodent pancreas. In this study, we performed the first direct functional analysis of Hhex in the fetal and adult endocrine pancreas, a primary organ responsible for glucose homeostasis. We employed two transgenic drivers for this purpose: Pdx1Cre-ER for inducible ablation in adult $\beta$ cells and most $\delta$ cells and Ngn3Cre for ablation in the entire fetal endocrine pancreas. We discovered that Hhex's primary function is not in pancreatic $\beta$ cells, as previously assumed, but in the maintenance of somatostatin $(\mathrm{Sst})$-producing $\delta$ cells and, consequently, in paracrine control of $\alpha$ - and $\beta$-cell function.

\section{Results and Discussion}

As a prerequisite toward understanding the potential role of Hhex in glucose homeostasis, we characterized its expression pattern in the adult pancreas. Coimmunofluorescent labeling of Hhex and individual hormone markers in the 9- to 12 -wk-old mouse pancreas revealed Hhex nuclear protein in pancreatic ducts and Sst-secreting $\delta$ cells (Fig. 1A). Contrary to expectation, we did not detect any Hhex immunoreactivity in insulin-producing $\beta$ cells or other endocrine cell types (Fig. 1B-D). In fact, $89 \%$ of Hhex-expressing cells coexpressed Sst, and, conversely, 94\% of Sst-positive cells were also Hhex-positive. Similar to our observation in mice, in the adult human pancreas, a strong nuclear HHEX signal was detected in Sst-expressing cells (Fig. 1E) rather than other endocrine cell types (Fig. 1F-H).

The $\delta$ cell, which comprises $6 \%$ of mouse and $11 \%$ of human islet cells (Brissova et al. 2005), contributes to glucose homeostasis in a paracrine fashion. In response to stimuli such as glucose and tolbutamide, the $\delta$ cell releases Sst, which binds to the Sst receptor 2 (Sstr2) on adjacent $\alpha$ cells and Sstr5 on $\beta$ cells to inhibit glucagon and insulin secretion, respectively (Moller et al. 2003). Islets from $S s t^{-1-}$ mice show elevated insulin and glucagon secretion in response to various secretagogues (Hauge-Evans et al. 2009). In addition, Sstr2-deficient mice, which lack paracrine inhibition specifically in $\alpha$ cells, are hyperglycemic due to elevated glucagon secretion (Singh et al. 2007).

In order to study the contribution of Hhex to islet function, we ablated Hhex in islet $\delta$ cells in mice. Due to the lack of a $\delta$-cell-specific Cre line, we used Pdx1-CreER $(\mathrm{Gu}$ et al. 2002) mice, in which Cre recombinase is active in both $\beta$ and $\delta$ cells upon induction by tamoxifen /Guz et al. 1995; Serup et al. 1995; Schaffer et al. 2011). We reasoned that because Hhex is not expressed in $\beta$ cells,

(c) 2014 Zhang et al. This article is distributed exclusively by Cold Spring Harbor Laboratory Press for the first six months after the full-issue publication date (see http://genesdev.cshlp.org/site/misc/terms.xhtml). After six months, it is available under a Creative Commons License (Attribution-NonCommercial 4.0 International), as described at http:// creativecommons.org/licenses/by-nc/4.0/. 


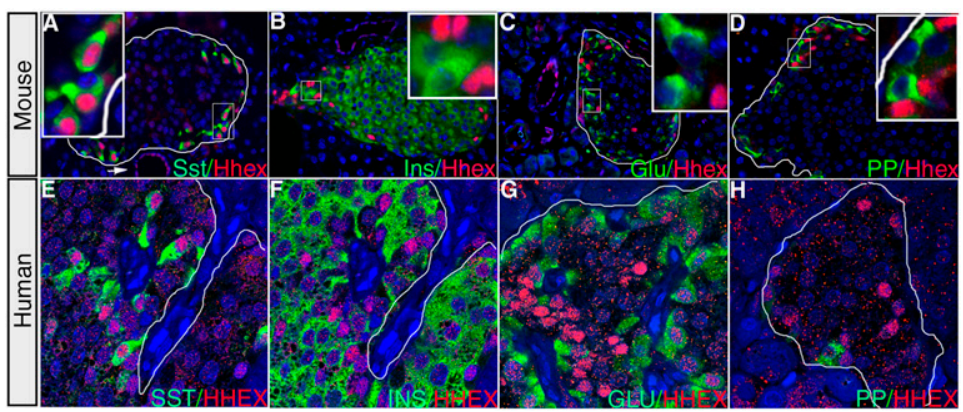

Figure 1. Hhex expression in the adult mouse and human pancreas. $|A|$ Immunofluorescent labeling of an adult mouse pancreas reveals robust Hhex expression in Sst-producing $\delta$ cells. Hhex immunoreactivity is also detected in pancreatic ducts (arrow) and, at lower levels, in some acinar cells. $(B-D)$ Hhex immunofluorescence is undetectable in insulin (Ins)-expressing $\beta$ cells, glucagon (Glu)-expressing $\alpha$ cells, or PP (pancreatic polypeptide) cells. (E-H) In the adult human pancreas, HHEX (red) is also expressed in Sst -positive (green) $\delta$ cells rather than other endocrine cell types. Borders of islets are outlined in white. these mice, once crossed with $H$ hex ${ }^{\text {LoxP }}\left(H h e x^{\text {LoxP/LoxP }}\right)$ mice, would allow us to analyze the $\delta$-cell-specific functions of Hhex. As predicted, when we ablated Hhex in 9- to 12-wk-old animals using Pdx1-CreER, by $1 \mathrm{wk}$ of tamoxifen treatment, insulin- and glucagon-producing cell numbers and islet architecture were normal, as evidenced by hormone immunofluorescence staining (Fig. 2A-B') and quantification of the endocrine cell area (Fig. 2E, F). In addition, immunoreactivity of two key $\beta$-cell signature genes, $\mathrm{Pdx} 1$ and Glut2, was indistinguishable between controls and mutants (Fig. 2C-D'). Consistent with this finding, we detected comparable mRNA levels of a spectrum of $\beta$-cell marker genes in control and mutant islets (Fig. 2G). As expected from the absence of Hhex expression in $\alpha$ and $\beta$ cells, these results confirm that Hhex does not act cell-autonomously in these cells.

In contrast to the lack of effect on $\alpha$ - and $\beta$-cell number, Sst immunolabeling revealed that mutant islets lost $>75 \%$ of $\delta$-cell area compared with controls (Fig. 3A-C). This finding was confirmed on the transcript level, where Sst expression in mutant islets was only $25 \%$ of that in the controls (Fig. 3D). In addition, Hhex mutant islets secreted $80 \%$ less Sst than control islets under both low (1 $\mathrm{mM})$ and high $(20 \mathrm{mM})$ glucose conditions, congruent with the reduced number of $\delta$ cells (Supplemental Fig. S1). Furthermore, expression of the cholecystokinin B receptor (Cckbr), a $\delta$-cell marker (Morisset et al. 2000), was significantly downregulated in Hhex-deficient islets (Fig. 3D), indicating $\delta$-cell dedifferentiation in the absence of Hhex. Of note, the remaining $\delta$ cells in Hhex mutants resulted from incomplete Hhex ablation, as most of them maintain Hhex expression (Fig. $\left.3 \mathrm{~B}^{\prime}\right)$. Collectively, these data demonstrate that Hhex is required for the maintenance of the $\delta$-cell phenotype in the adult islet.

To determine whether Hhex also controls $\delta$-cell differentiation during fetal development, we employed Ngn3Cre (Schonhoff et al. 2004) to inactivate Hhex in endocrine progenitors. Hhex ${ }^{\text {loxP/loxP }}$;
Ngn3Cre mice displayed a complete loss of Sst ${ }^{+}$ cells in islets at embryonic day 16.5 (E16.5) and 16 wk of age, indicating an essential role of Hhex in $\delta$-cell differentiation (Fig. 4). Note that, similar to our adult gene ablation model, $\beta$-cell number was not affected by Hhex deficiency.

Next, we explored the functional consequences of Hhex deficiency in adult $\delta$ cells. To evaluate glucose responsiveness, we challenged control and Hhex mutant mouse islets with a glucose ramp $(0-25 \mathrm{mM})$ in the islet perifusion assay. Compared with controls, mutant islets exhibited both a lower glucose response threshold and enhanced overall insulin secretion (Fig. 3E). The unbridled insulin secretion in mutants stemmed from Hhex deficiency rather than ectopic expression of Cre in the $\beta$ cell from the Pdx1-CreER transgenes, whose lack of effect on insulin secretion has been validated in several reports (Lee et al. 2011; Schaffer et al. 2011; Gao et al. 2014).

To examine glucagon secretory capacity, we employed static islet cultures. At the basal condition (16.7 mM glucose), glucagon release from control and mutant mouse islets was indistinguishable (Fig. 3F). However, when stimulated by lowering the glucose concentration from $16.7 \mathrm{mM}$ to $2.8 \mathrm{mM}$ and simultaneously adding an amino acid mixture as a glucagon secretagogue, mutant islets secreted twice as much glucagon as the controls (Fig. 3F). As predicted, elevated
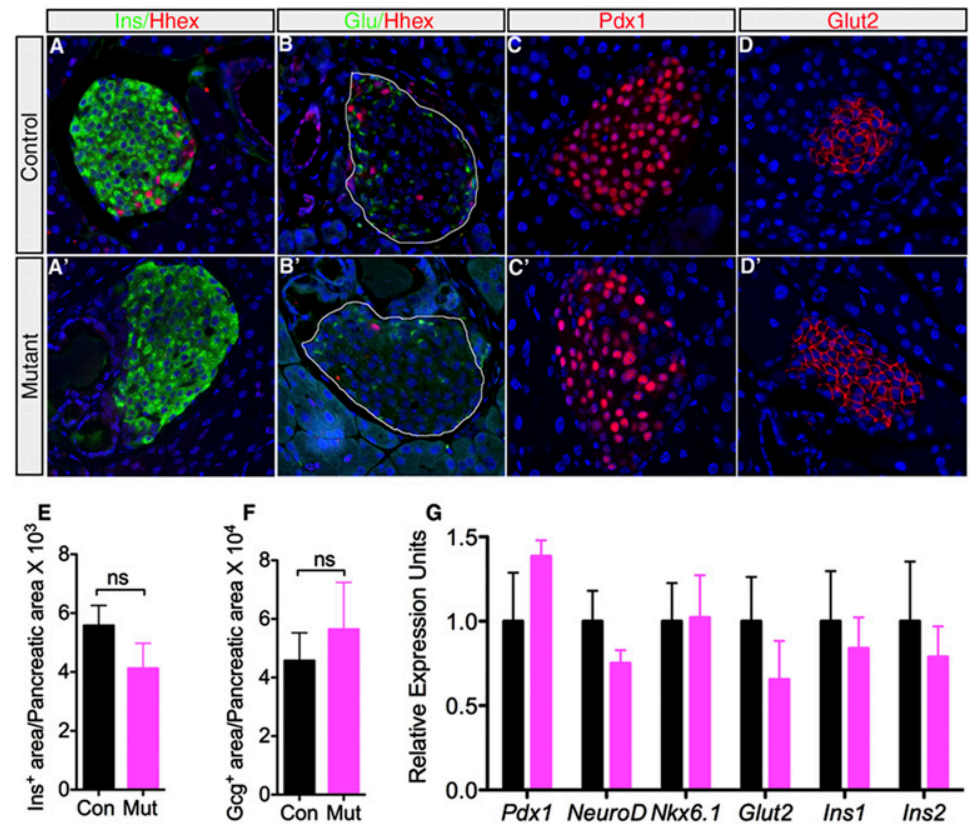

Figure 2. Acute Hhex ablation does not adversely affect $\alpha$ - and $\beta$-cell numbers. $\left(A-B^{\prime}\right)$ Normal $\alpha$ - and $\beta$-cell number and islet architecture in the Hhex mutant (Hhex ${ }^{\text {LoxP/loxP }}$;Pdx1-CreER mice treated with tamoxifen) and control (Hhex ${ }^{\text {LoxP/LoxP }}$ mice treated with tamoxifen) pancreas as revealed by immunofluorescent staining. Islet areas are outlined in $B$ and $B^{\prime} .\left(C-D^{\prime}\right)$ Immunolabeling showed that expression of key $\beta$-cell markers Pdx1 and Glut2 is indistinguishable in control and Hhex mutants. $(E, F) \beta$-Cell and $\alpha$-cell areas in Hhex mutants are similar to those seen in controls $(n=4)$. $(G)$ Transcript levels of $\beta$-cell signature genes $P d x 1$, NeuroD, Nkx6.1, Glut2, Ins1, and Ins2 are comparable between controls and Hhex mutants as evaluated by qRT-PCR $(n=4-6)$. Data are represented as mean \pm SEM. (ns) Not significant. 

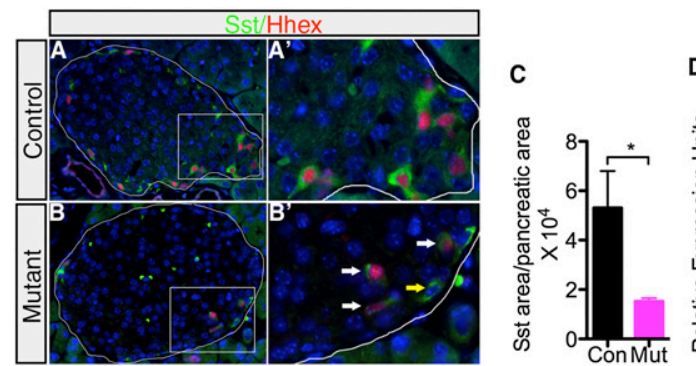

D
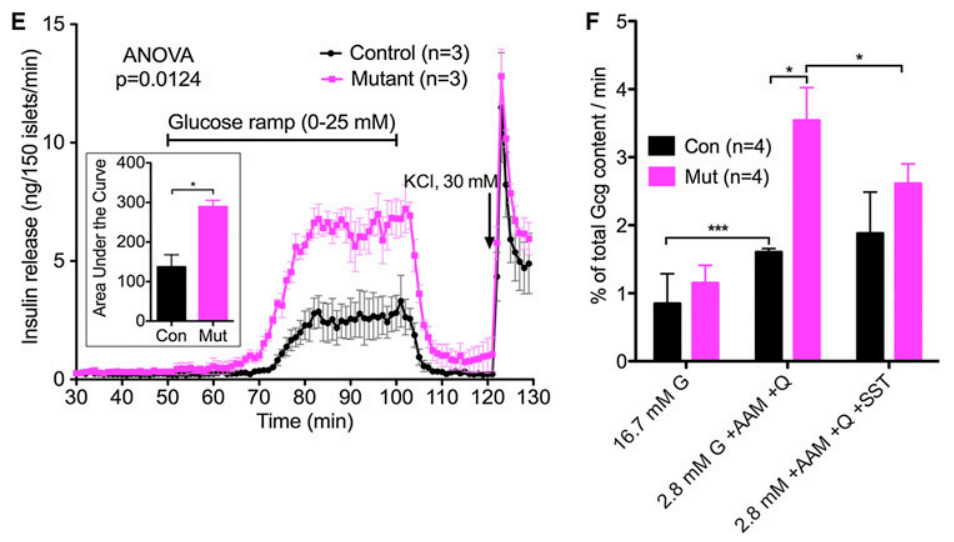

Figure 3. Hhex deficiency in the adult pancreas results in the reduction of $\delta$ cells and compromised islet function. $(A, B)$ Representative immunofluorescent costaining of Hhex (red) and Sst (green) in control and mutant animals. Note the decrease of $\mathrm{Sst}^{+}$cell number in the mutant pancreas. Islets are outlined. $\left(A^{\prime}, B^{\prime}\right)$ Magnified view of boxed regions in $A$ and $B$, respectively. White arrows in $B^{\prime}$ designate remaining $\delta$ cells in mutant islets positive for Hhex. Yellow arrow denotes a rare $\mathrm{Sst}^{+}{ }_{;} \mathrm{Hhex}^{-}$cell. $(C)$ Ratio of $\mathrm{Sst}^{+}$area to pancreatic area in control $(n=3)$ and mutant $(n=4)$ mice. $(D)$ qRT-PCR detection of Hhex, Sst, and Cckbr transcripts in control $(n=4-6)$ and mutant $(n=4)$ islets. $(E)$ Islet perifusion assays on islets from 9-wk-old control $(n=3)$ and mutant $(n=3)$ littermates show abnormally enhanced insulin secretion in response to a glucose ramp $(0-25 \mathrm{mM})$. The area below the curve was calculated for insulin release tracks and is plotted in the insert. $(F)$ Glucagon release in response to a cocktail of glucagon secretagogues $(2.8 \mathrm{mM}$ glucose $[\mathrm{G}], 7 \mathrm{mM}$ amino acid mixture [AAM], and $1 \mathrm{mM}$ glutamine $[\mathrm{Q}])$ alone or in combination with Sst $(2.4 \mu \mathrm{M})$ was examined in static islet incubations $(n=4)$. Control (Con) indicates Hhex ${ }^{\text {LoxP/LoxP }}$ with tamoxifen. Mutant (Mut) indicates Hhex ${ }^{\text {Loxp }} ; P d x 1-C r e E R$ with tamoxifen. Data in all graphs are represented as mean \pm SEM. $\left(^{\star}\right) P<0.05$; $\left(^{\star \star \star}\right) P<0.001$. See also Supplemental Figures S1 and S2.

glucagon secretion in mutants was partially reversed by treatment with $2.4 \mu \mathrm{M}$ Sst, confirming that the secretory defect in Hhex mutant islets was due to $\delta$-cell dysfunction (Fig. 3F). In summary, loss of Hhex disrupts inhibitory paracrine regulation by the $\delta$ cell, resulting in abnormally enhanced insulin and glucagon release in response to stimuli. These findings establish a role for Hhex in normal islet physiology by maintaining $\delta$-cell number and function. Although impaired $\delta$-cell function in 9- to 10-wk-old Hhex mutants did not compromise glucose tolerance (Supplemental Fig. S2A), likely due to the counteracting effect from elevated glucagon release, Hhex deficiency resulted in enhanced fasting and overall plasma insulin concentrations after glucose injections (Supplemental Fig. S2B), confirming dampened paracrine control on insulin secretion.

Next, we sought to investigate the molecular mechanisms of how Hhex controls $\delta$-cell number. We speculated that Hhex might contribute to $\delta$-cell survival. Therefore, we screened for apoptotic cells via TUNEL (terminal deoxynucleotidyl transferase [TdT]-mediated dUTP nick end labeling) and cleaved caspase-3 immunolabeling in Hhex mutant pancreata at multiple time points following the first tamoxifen injection (Supplemental Fig. S3; data not shown). However, we did not find any evidence of increased apoptosis at any time point examined. We thus conclude that the absence of Hhex does not affect $\delta$-cell survival.

Alternatively, Hhex could be a direct transcriptional activator of the Sst gene. We addressed this possibility using multiple means. We began by assessing whether there is a direct dominant activity of Hhex on the Sst promoter. Overexpression of human HHEX protein in MIN6 (mouse insulinoma) $\beta$ cells (Miyazaki et al. 1990; Ishihara et al. 1993) induced an $\sim 35$-fold increase in endogenous Sst mRNA expression as demonstrated by quantitative RT-PCR (qRT-PCR) (Fig. 5A). In contrast, ectopic HHEX expression in nonendocrine HeLa cells failed to augment Sst levels (Fig. 5B), suggesting a context-dependent role of HHEX in controlling Sst transcription. Furthermore, chromatin immunoprecipitation (ChIP) assays in MIN6 cells overexpressing the HHEX protein demonstrated HHEX binding at two specific loci (100 base pairs [bp] and $380 \mathrm{bp}$ upstream of the Sst transcriptional start site [TSS]) within the endogenous Sst promoter (Fig. 5C). A 676-bp-long proximal element of the Sst promoter encompassing these Hhex-binding sites exhibited robust activity in luciferase reporter assays. Mutation of the core Hhexbinding motif ATTA to CCCC diminished the activity of the Sst proximal promoter by $80 \%$ (Fig. 5D). These findings suggest that Hhex directly activates Sst transcription.

In summary, we report Hhex as the first transcription factor specifically required for $\delta$-cell maintenance. We further demonstrate that Hhex contributes to islet function not by controlling $\beta$-cell physiology directly but by maintaining the differentiated phenotype of the $\delta$ cell and thus paracrine regulation of $\beta$-cell activity. These findings suggest that misregulated HHEX expression within the diabetic islet might contribute to disrupted paracrine control of insulin secretion in T2DM, leading to accelerated $\beta$-cell exhaustion and $\beta$-cell failure. In the future, it will be interesting to determine the fate of the Hhex-deficient, dedifferentiated $\delta$ cells using genetic lineage tracing once a robust, $\delta$-cell-specific CreER transgenic line becomes available.

\section{Materials and methods}

\section{Mice}

The derivation of the Hhex ${ }^{\text {LoxP }}$ allele has been described previously (Hunter et al. 2007). Pdx1CreER mice (Gu et al. 2002) were kindly provided by Dr. Guoqiang Gu and Dr. Doug Melton. Ngn3Cre mice were purchased from Jackson Laboratory. All mice were maintained on a mixed 129SvEv/C57BL/6 background. Genotyping was performed by PCR analysis using genomic DNA isolated from the tail tips of newborn mice. Adult mice (9-12 wk of age) were used in all experiments. To induce gene ablation, $1.6 \mathrm{mg}$ of tamoxifen (Sigma) was injected into Hhex ${ }^{\text {LoxP }}$ (control) and Hhex ${ }^{\text {LoxP }}$;Pdx1-CreER (mutant) animals on three consecutive days. All experiments were performed $3 \mathrm{~d}$ after the last 


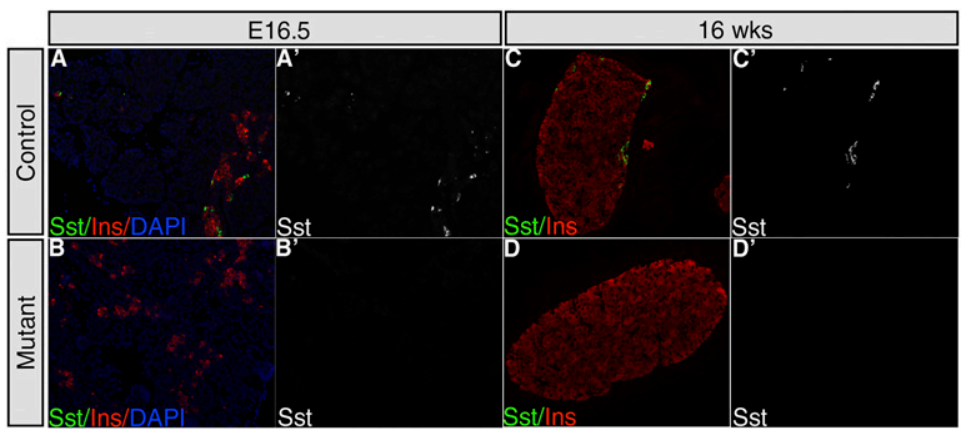

Figure 4. Hhex deficiency in endocrine progenitors leads to loss of $\delta$ cells. Hhex was ablated during fetal pancreatic development using the Ngn3Cre transgene. Representative images of Sst and insulin double immunolabeling in a control $\left(H\right.$ Hex $\left.^{\mathrm{LoxP}}\right)$ and mutant $\left(H\right.$ Hex $^{\mathrm{LoxP}}$; Ngn3Cre) pancreas at E16.5 $\left(A-B^{\prime}\right)$ and $16 \mathrm{wk}$ $\left(C-D^{\prime}\right) .\left(B, B^{\prime}, D, D^{\prime}\right)$ Note the absence of Sst ${ }^{+}$cells in Hhex-deficient mice.

injection unless noted otherwise. All procedures involving mice were conducted in accordance with approved Institutional Animal Care and Use Committee protocols.

\section{Histological analysis}

For all histological studies, pancreata were dissected and fixed in $4 \%$ paraformaldehyde for $24 \mathrm{~h}$ at $4^{\circ} \mathrm{C}$ before paraffin embedding and sectioning. For immunohistochemistry of Sst, slides were blocked with Avidin $\mathrm{D}$ and biotin blocking reagents (Vector Laboratories) for $15 \mathrm{~min}$ at room temperature, with a quick rinse of PBS in between. Subsequently, slides were incubated with rabbit anti-Sst (1:250 dilution; Santa Cruz Biotechnology) overnight at $4^{\circ} \mathrm{C}$ followed by secondary antibody (biotinylated donkey anti-rabbit [1:500; Vector Laboratories]) incubation for $2 \mathrm{~h}$ at room temperature. Signals were developed using the 3,3'diaminobenzidine (DAB) kit (Vector Laboratories).

For immunofluorescent staining, antigen retrieval was performed in citric acid buffer (pH 6.0) in the 2100 classic clinical autoclave (Prestige Medical) for $1 \mathrm{~h}$ followed by $15 \mathrm{~min}$ of cooling in running water. All slides were blocked with Casblock (Invitrogen) for $15 \mathrm{~min}$ at room temperature. The primary antibodies (rabbit anti-Hhex [1:300] [Hunter et al. 2007), goat anti-Sst [1:250; Santa Cruz Biotechnology], guinea pig anti-insulin [1:250, Millipore], goat anti-glucagon [1:250; Santa Cruz Biotechnology], goat anti-anti-pancreatic polypeptide [1:250; Santa Cruz Biotechnology], goat anti-ghrelin [1:250; Santa Cruz Biotechnology], and rabbit anti-cleaved caspase-3 [1:750; Cell Signaling]) were diluted in Casblock and incubated overnight at $4^{\circ} \mathrm{C}$. Secondary antibody incubation was performed with species-specific fluorophore-labeled secondary antibodies (1:500; Jackson ImmunoResearch Laboratories) for $2 \mathrm{~h}$ at room temperature. Nuclei were stained with 4',6-diamidino-2-phenylindole (DAPI) (Invitrogen). Confocal fluorescent imaging was visualized using a Zeiss LSM 510 NLO/META confocal microscope at $60 \times$. TUNEL staining was performed using the TUNEL labeling kit from R\&D Systems according to the manufacturer's instructions.

To quantify the ratio of hormone ${ }^{+}$area to pancreas area, whole pancreata were removed, laid out flat, and fixed as above. Five-micrometer longitudinal sections were prepared, with $50-\mu \mathrm{m}$ intervals between sections. Every sixth section (a total of three to four sections per pancreas) was used for hormone immunoperoxidase labeling. This sampling method spans $>50 \%$ of the pancreatic volume. In addition, care was taken to score equivalent regions of control and mutant specimens. After immunohistochemical staining, $100 \%$ of each hormone-labeled section was scanned at $4 \times$ (for insulin and glucagon immunostaining signal) or $20 \times$ (for Sst immunostaining signal) magnification. The areas of positive signal and the total pancreatic areas were measured by ImageJ (Schneider 2012).

\section{Islet insulin and glucagon secretion}

Islets were isolated from control and mutant mice using standard collagenase digestion followed by purification through a Ficoll gradient
(Gao et al. 2007). To measure insulin release in response to glucose, islet perifusion was performed as previously described (Gao et al. 2010) after overnight culture at $37^{\circ} \mathrm{C}$. Insulin content was determined using radioimmunoassay by the Radioimmunoassay and Biomarkers Core at the University of Pennsylvania. Glucagon release was measured by static secretion assay. Islets were preincubated for $60 \mathrm{~min}$ in buffer containing $16.7 \mathrm{mM}$ glucose in a 96-well plate (80 islets per well), after which islets were challenged by the following conditions at $37^{\circ} \mathrm{C}: 16.7 \mathrm{mM}$ glucose for $1 \mathrm{~h} ; 2.8 \mathrm{mM}$ glucose with $7 \mathrm{mM}$ amino acid mixture and $1 \mathrm{mM}$ glutamine for $30 \mathrm{~min}$; and $2.8 \mathrm{mM}$ glucose with $7 \mathrm{mM}$ amino acid mixture, $1 \mathrm{mM}$ glutamine, and $2.4 \mu \mathrm{M}$ Sst-14 (Sigma) for $30 \mathrm{~min}$. Glucagon content was assayed by commercial EIA kit according to the manufacturer's instructions (glucagon EIA kit, R\&D Systems). For assessment of total islet hormone content, islets were sedimented by centrifugation, washed with PBS, and sonicated in RIPA buffer.

\section{$R N A$ extraction and $q R T-P C R$}

Total RNA from mouse islets or MIN6 cells was extracted using RNeasy minikit (Qiagen) and analyzed by qRT-PCR as described previously (Le Lay et al. 2009). qRT-PCR primer sequences are available on request.

\section{MIN6 cell culture and ChIP}

MIN6 cells were maintained in DMEM containing 10\% FBS and $25 \mathrm{mM}$ glucose at $37^{\circ} \mathrm{C}$ in $5 \% \mathrm{CO}_{2}$. Two micrograms of pMUG-Myc-HHEX plasmid or pMUG vector (Swingler et al. 2004) was introduced via nucleofection (Amaxa Biosystems) (Liu et al. 2010). Cells were harvested
A
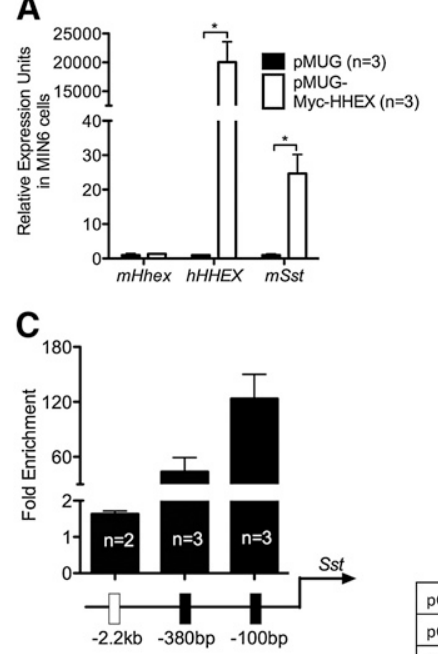

B
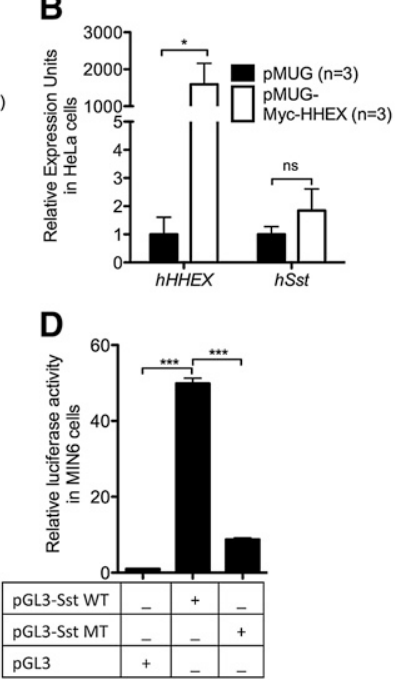

Figure 5. Hhex maintains $\delta$-cell number through transcriptional up-regulation of Sst rather than affecting apoptosis. (A) Ectopic expression of HHEX is sufficient to induce Sst expression in MIN6 cells transfected with a Myc-tagged HHEX expression plasmid $(n=$ 3). (B) Overexpression of HHEX in HeLa cells fails to activate $S s t(n=$ 3). (C) ChIP using an anti-Myc 9E10 antibody was performed on Myc-tagged HHEX-expressing MIN6 cells followed by qPCR evaluation of enrichment at three putative binding sites of Hhex within the Sst promoter. Data are presented as the fold enrichment of the target amplicon in ChIP DNA compared with input DNA $(n=2$ or 3). (D) Dual-luciferase reporter assays were conducted in MIN6 cells transfected with reporter constructs containing the intact (pGL3-Sst WT) or mutated (pGL3-Sst MT) proximal promoter of Sst or the basic vector pGL3 $(n=3)$. Data are represented as mean \pm SEM. $\left(^{\star}\right) P<0.05 ;\left(^{* \star *}\right) \mathrm{P}<0.001$; (ns) not significant. See also Supplemental Figure S3. 
$48 \mathrm{~h}$ after transfection for ChIP assays or RNA extraction. ChIP assays were performed following the protocol in Le Lay et al. (2009) using Myc9E10 antibody (Abcam) followed by qRT-PCR validation with the following primers: Sst-2.2kb-F, GGAAAAATTTGCACTGCCTCT; Sst-2.2kb-R，TGAGGCTGTAGATGAGATGACG; Sst-380-F, TGCAA GTCCAGTAATCTGGGTA; Sst-380-R, TCAGCCACATAGGAGCAC AC; Sst-100-F, CCTCCCCTCACTTCTGTGAT; and Sst-100-R, TCC ACGGTCTCCCCTTTTTA.

\section{Luciferase reporter assays}

A 676-bp fragment (-576 to +100 bp relative to the TSS) of the Sst promoter spanning the Hhex-binding sites was PCR-cloned in the NheI and XhoI sites of the pGL3 basic vector to build pGL3-Sst wild-type construct. A mutated version of this element was synthesized by Eurofins MWG Operon and subsequently inserted into pGL3 basic vector at the NheI and XhoI sites, resulting in mutated pGL3-Sst. One microgram of pGL3 basic vector, pGL3-Sst wild type, or pGL3-Sst mutant mixed with $10 \mathrm{ng}$ of pHRL (Invitrogen) was introduced into $\sim 1 \times 10^{6}$ cells via Lipofectamine (Invitrogen). A dual luciferase reporter assay was performed $48 \mathrm{~h}$ after transfection according to the manufacturer's instruction (Promega). Luciferase activity was normalized for transfection efficiency by corresponding Renilla luciferase activity. Experiments were performed on three biological triplicates.

\section{Statistical methods}

Statistical analysis between two groups was performed using a two-tailed Student's $t$-test unless noted otherwise. Values were considered significant when $P<0.05$. Variation measurements are given as standard error of the mean.

\section{Acknowledgments}

We thank Dr. Guoqiang Gu and Dr. Douglas Melton for sharing Pdxl-CreER mice, Dr. Padma-Sheela Jayaraman for providing the pMUGMyc-HHEX plasmid, and Dr. Joshua Friedman for valuable comments on the manuscript. We are grateful to Karrie Brondell and Tia Bernard for maintenance of the mouse colonies, and Itai Doron and Xiao Ji for technical assistance. We thank the Morphology Core of the Penn Center for Molecular Studies in Liver and Digestive Disease (P30-DK050306) for reagents and technical assistance. We appreciate the help of Dr. Franz M. Matschinsky and Wei Qin at the Islet Cell Biology Core of the University of Pennsylvania Diabetes Research Center (P30-DK19525) for islet perifusion assays. This work was funded by National Institutes of Health grant R01DK055342 and American Diabetes Association grant number 7-12-MN-37 to K.H.K.

\section{References}

Bogue CW, Ganea GR, Sturm E, Ianucci R, Jacobs HC. 2000. Hex expression suggests a role in the development and function of organs derived from foregut endoderm. Dev Dyn 219: 84-89.

Bort R, Martinez-Barbera JP, Beddington RS, Zaret KS. 2004. Hex homeobox gene-dependent tissue positioning is required for organogenesis of the ventral pancreas. Development 131: 797-806.

Bort R, Signore M, Tremblay K, Martinez Barbera JP, Zaret KS. 2006. Hex homeobox gene controls the transition of the endoderm to a pseudostratified, cell emergent epithelium for liver bud development. Dev Biol 290: 44-56.

Brissova M, Fowler MJ, Nicholson WE, Chu A, Hirshberg B, Harlan DM, Powers AC. 2005. Assessment of human pancreatic islet architecture and composition by laser scanning confocal microscopy. J Histochem Cytochem 53: 1087-1097.

Fagman H, Nilsson M. 2011. Morphogenetics of early thyroid development. J Mol Endocrinol 46: R33-R42.

Foley AC, Mercola M. 2005. Heart induction by Wnt antagonists depends on the homeodomain transcription factor Hex. Genes Dev 19: 387396.

Gao N, White P, Doliba N, Golson ML, Matschinsky FM, Kaestner KH. 2007. Foxa2 controls vesicle docking and insulin secretion in mature $\beta$ cells. Cell Metab 6: 267-279.
Gao N, Le Lay J, Qin W, Doliba N, Schug J, Fox AJ, Smirnova O, Matschinsky FM, Kaestner KH. 2010. Foxal and Foxa2 maintain the metabolic and secretory features of the mature $\beta$-cell. Mol Endocrinol 24: 1594-1604.

Gao T, McKenna B, Li C, Reichert M, Nguyen J, Singh T, Yang C, Pannikar A, Doliba N, Zhang T, et al. 2014. Pdx1 maintains $\beta$ cell identity and function by repressing an $\alpha$ cell program. Cell Metab 19: 259-271.

Gu G, Dubauskaite J, Melton DA. 2002. Direct evidence for the pancreatic lineage: $\mathrm{NGN}^{+}$cells are islet progenitors and are distinct from duct progenitors. Development 129: 2447-2457.

Guz Y, Montminy MR, Stein R, Leonard J, Gamer LW, Wright CV, Teitelman G. 1995. Expression of murine STF-1, a putative insulin gene transcription factor, in $\beta$ cells of pancreas, duodenal epithelium and pancreatic exocrine and endocrine progenitors during ontogeny. Development 121: 11-18.

Hauge-Evans AC, King AJ, Carmignac D, Richardson CC, Robinson IC, Low MJ, Christie MR, Persaud SJ, Jones PM. 2009. Somatostatin secreted by islet $\delta$-cells fulfills multiple roles as a paracrine regulator of islet function. Diabetes 58: 403-411.

Hunter MP, Wilson CM, Jiang X, Cong R, Vasavada H, Kaestner KH, Bogue CW. 2007. The homeobox gene Hhex is essential for proper hepatoblast differentiation and bile duct morphogenesis. Dev Biol 308: $355-367$.

Ishihara $\mathrm{H}$, Asano $\mathrm{T}$, Tsukuda $\mathrm{K}$, Katagiri $\mathrm{H}$, Inukai $\mathrm{K}$, Anai M, Kikuchi M, Yazaki Y, Miyazaki JI, Oka Y. 1993. Pancreatic $\beta$ cell line MIN6 exhibits characteristics of glucose metabolism and glucose-stimulated insulin secretion similar to those of normal islets. Diabetologia 36: 1139-1145.

Jonsson A, Ladenvall C, Ahluwalia TS, Kravic J, Krus U, Taneera J, Isomaa B, Tuomi T, Renstrom E, Groop L, et al. 2013. Effects of common genetic variants associated with type 2 diabetes and glycemic traits on $\alpha$ - and $\beta$-cell function and insulin action in humans. Diabetes 62: 2978-2983.

Lee AH, Heidtman K, Hotamisligil GS, Glimcher LH. 2011. Dual and opposing roles of the unfolded protein response regulated by IRE1 $\alpha$ and XBP1 in proinsulin processing and insulin secretion. Proc Natl Acad Sci 108: $8885-8890$.

Le Lay J, Tuteja G, White P, Dhir R, Ahima R, Kaestner KH. 2009. CRTC2 (TORC2) contributes to the transcriptional response to fasting in the liver but is not required for the maintenance of glucose homeostasis. Cell Metab 10: 55-62.

Liu J, Wang Y, Birnbaum MJ, Stoffers DA. 2010. Three-amino-acid-loopextension homeodomain factor Meis3 regulates cell survival via PDK1. Proc Natl Acad Sci 107: 20494-20499.

Miyazaki J, Araki K, Yamato E, Ikegami H, Asano T, Shibasaki Y, Oka Y, Yamamura K. 1990. Establishment of a pancreatic $\beta$ cell line that retains glucose-inducible insulin secretion: special reference to expression of glucose transporter isoforms. Endocrinology 127: 126-132.

Moller LN, Stidsen CE, Hartmann B, Holst JJ. 2003. Somatostatin receptors. Biochim Biophys Acta 1616: 1-84.

Morisset J, Wong H, Walsh JH, Laine J, Bourassa J. 2000. Pancreatic CCK(B) receptors: their potential roles in somatostatin release and $\delta$-cell proliferation. Am I Physiol Gastrointest Liver Physiol 279: G148-G156.

Saxena R, Voight BF, Lyssenko V, Burtt NP, de Bakker PI, Chen H, Roix JJ, Kathiresan S, Hirschhorn JN, Daly MJ, et al. 2007. Genome-wide association analysis identifies loci for type 2 diabetes and triglyceride levels. Science 316: 1331-1336.

Schaffer AE, Yang AJ, Thorel F, Herrera PL, Sander M. 2011. Transgenic overexpression of the transcription factor Nkx6.1 in $\beta$-cells of mice does not increase $\beta$-cell proliferation, $\beta$-cell mass, or improve glucose clearance. Mol Endocrinol 25: 1904-1914.

Schneider CA, Rasband WS, Eliceiri KW. 2012. NIH Image to ImageJ: 25 years of image analysis. Nat Methods 9: 671-675.

Schonhoff SE, Giel-Moloney M, Leiter AB. 2004. Neurogenin 3-expressing progenitor cells in the gastrointestinal tract differentiate into both endocrine and non-endocrine cell types. Dev Biol 270: 443-454.

Schulze MB, Al-Hasani H, Boeing H, Fisher E, Doring F, Joost HG. 2007. Variation in the HHEX-IDE gene region predisposes to type 2 diabetes in the prospective, population-based EPIC-Potsdam cohort. Diabetologia 50: 2405-2407. 


\section{Zhang et al.}

Scott LJ, Mohlke KL, Bonnycastle LL, Willer CJ, Li Y, Duren WL, Erdos MR, Stringham HM, Chines PS, Jackson AU, et al. 2007. A genome-wide association study of type 2 diabetes in Finns detects multiple susceptibility variants. Science 316: 1341-1345.

Serup P, Petersen HV, Pedersen EE, Edlund H, Leonard J, Petersen JS, Larsson LI, Madsen OD. 1995. The homeodomain protein IPF-1/STF-1 is expressed in a subset of islet cells and promotes rat insulin 1 gene expression dependent on an intact E1 helix-loop-helix factor binding site. Biochem J 310: 997-1003.

Singh V, Grotzinger C, Nowak KW, Zacharias S, Goncz E, Pless G, Sauer IM, Eichhorn I, Pfeiffer-Guglielmi B, Hamprecht B, et al. 2007. Somatostatin receptor subtype-2-deficient mice with diet-induced obesity have hyperglycemia, nonfasting hyperglucagonemia, and decreased hepatic glycogen deposition. Endocrinology 148: 3887-3899.

Steneberg P, Bernardo L, Edfalk S, Lundberg L, Backlund F, Ostenson CG Edlund H. 2013. The type 2 diabetes-associated gene ide is required for insulin secretion and suppression of $\alpha$-synuclein levels in $\beta$-cells. Diabetes 62: 2004-2014.

Swingler TE, Bess KL, Yao J, Stifani S, Jayaraman PS. 2004. The prolinerich homeodomain protein recruits members of the Groucho/ Transducin-like enhancer of split protein family to co-repress transcription in hematopoietic cells. I Biol Chem 279: 3493834947.

Zhao J, Bradfield JP, Zhang H, Annaiah K, Wang K, Kim CE, Glessner JT, Frackelton EC, Otieno FG, Doran J, et al. 2010. Examination of all type 2 diabetes GWAS loci reveals HHEX-IDE as a locus influencing pediatric BMI. Diabetes 59: 751-755. 


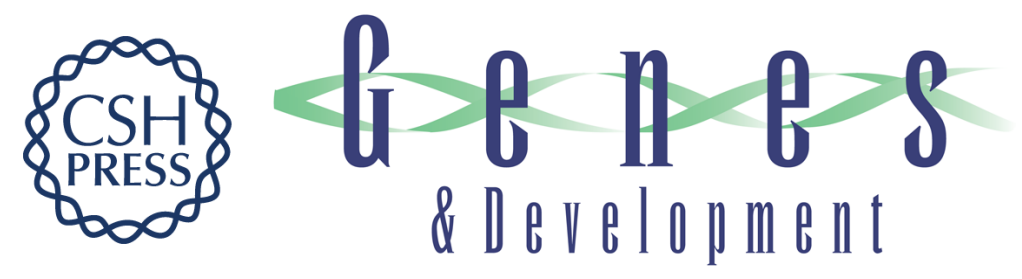

\section{The diabetes gene Hhex maintains $\delta$-cell differentiation and islet function}

Jia Zhang, Lindsay B. McKenna, Clifford W. Bogue, et al.

Genes Dev. 2014, 28:

Access the most recent version at doi:10.1101/gad.235499.113

\section{Supplemental http://genesdev.cshlp.org/content/suppl/2014/04/15/28.8.829.DC1 Material}

References This article cites 32 articles, 14 of which can be accessed free at: http://genesdev.cshlp.org/content/28/8/829.full.html\#ref-list-1

Creative This article is distributed exclusively by Cold Spring Harbor Laboratory Press for the first Commons six months after the full-issue publication date (see

License http://genesdev.cshlp.org/site/misc/terms.xhtml). After six months, it is available under a Creative Commons License (Attribution-NonCommercial 4.0 International), as described at http://creativecommons.org/licenses/by-nc/4.0/.

Email Alerting Receive free email alerts when new articles cite this article - sign up in the box at the top Service right corner of the article or click here.

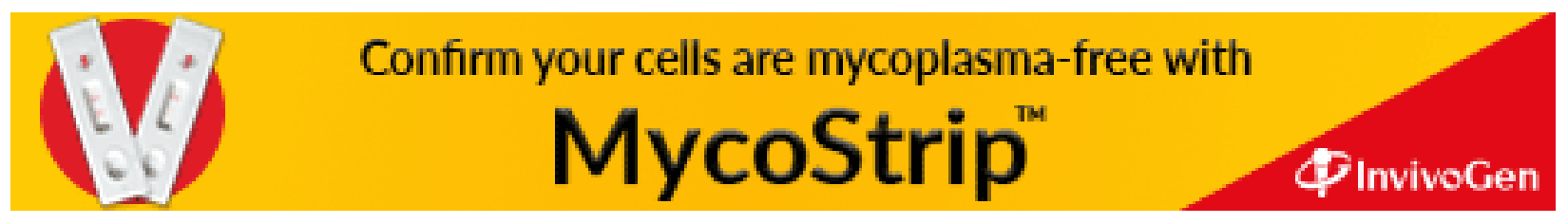

